czasowej zmiany miejsca pobytu, sezonowości itd.). Interesującym zagadnieniem jest też kwestia „utowarowienia” sportu, która może być rozpatrywana nie tylko w kontekście turystyki sportowej, ale także w odniesieniu do innych form turystyki.

\title{
Bibliografia
}

ALEJZIAK W., 1999, Turystyka wo obliczu wyzwań XXI wieku, Albis, Kraków.

GETZ D., 2008, Event tourism: Definition, evolution, and research, „Tourism Management”, 29, s. 403-428.

GRABOWSKI H., 1984, Teoria wychowania fizycznego, AWF, Kraków.

GIBSON H.J., 1998, Sport tourism: a critical analysis of research, „Sport Management Review”, 1, s. 45-76.

GLYPTIS S.A., 1991, Sport and tourism, [w:] In Progress in Tourism, Recreation and Hospitality Management, C. Cooper (ed.), Belhaven, London, s. 165-183.

HALL C.M., 1992, Adventure, sport and health tourism, [w:] Special Interest Tourism, B. Weile, C.M. Hall (eds.), Belhaven Press, London, s. $141-158$

HINCH T.D., HigHAM J.E.S., 2001, Sport Tourism: a Framework for Research, „International Journal of Tourism Research”, 3, s. 45-58.

KAGANEK K., 2015, Różnorodność pojęć w zakresie aktywnego uprawiania turystyki, [w:] Wczoraj, dziś i jutro turystyki aktywnej i specjalistycznej, A. Stasiak, J. Śledzińska, B. Włodarczyk (red.), Wyd. PTTK „Kraj”, Warszawa, s. 26-38.

ŁOBOŻEWICZ T., 2001, Miejsce turystyki w naukach o kulturze fizycznej, „Zeszyty Naukowe AWF Kraków”, 81: Cele i treści akademickiego ksztatcenia w dziedzinie turystyki i rekreacji, s. 13-20.

MOKRAS-GRABOWSKA J., 2015, Turystyka aktywna - zagadnienia terminologiczne i klasyfikacje, [w:] Wczoraj, dziś i jutro turystyki aktywnej i specjalistycznej, A. Stasiak, J. Śledzińska, B. Włodarczyk (red.), Wyd. PTTK „Kraj”, Warszawa, s. 11-25.

STANDEVEN J., De KNOP P., 1999, Sport Tourism, Human Kinetics, Champaign, Illinois.

WEED M.E., BULL C.J., 1997, Influences on sport-tourism relations in Britain: the effects of government policy, "Tourism Recreation Research”, 22(2), s. 5-12.

WINIARSKI R., 1989, Wstęp do teorii rekreacji (ze szczególnym uwzzlędnieniem rekreacji fizycznej), wyd. skryptowe, 100, AWF Kraków.

http://dx.doi.org/10.18778/0867-5856.26.1.11

\author{
Stefan Bosiacki \\ Akademia Wychowania Fizycznego w Poznaniu \\ Katedra Ekonomiki i Organizacji Turystyki

\section{TURYSTYKA SPORTOWA - O SEMANTYCZNYM NIEPOROZUMIENIU REFLEKSJI KILKA}

We współczesnym świecie sport staje się nie tylko potężnym "przemysłem”, generującym gigantyczne obroty finansowe, ale także znaczącym elementem sfery kultury. Miasta coraz usilniej zabiegają o organizację znaczących wydarzeń sportowych, które są doskonałym instrumentem promocji danego obszaru (miejscowości), tworzenia pozytywnego wizerunku miasta, a w konsekwencji instrumentem aktywizacji lokalnej gospodarki, w tym także gospodarki turystycznej.

Jak słusznie zauważa A. SMITH (2001, s. 129): „dla lokalnych władz sport uosabia nową erę i jest nową drogą dla miast cierpiących na postindustrialny kryzys tożsamości”. Wydarzenia sportowe związane z nimi, pozytywne emocje, obecność w krajowych i międzynarodowych mediach są doskonałym sposobem na zmianę wizerunku miasta lub regionu.

O ile w latach 80. XX w. sport i turystyka postrzegane były przez badaczy i praktyków gospodarczych jako odrębne sfery ludzkiej aktywności, o tyle współcześnie coraz częściej próbuje się łączyć te sfery, a przy okazji tworzyć nowe reguły semantyczne, nie zawsze w pełni uprawnione. Takim pojęciem jest bez wątpienia "turystyka sportowa”, najczęściej definiowana jako „wszelkie formy aktywnego i biernego zaangażowania w działalność sportową, indywidualnego lub zorganizowanego w celach niekomercyjnych lub biznesowo-komercyjnych, które wymagają podróży z dala od domu i miejsca pracy" (STANDEVEN, DE KNOP 1999, s. 12).

Badacze zajmujący się turystyką sportową wyróżniają przy tym cztery jej kategorie, tj. turystykę zawierającą elementy sportu, turystykę $\mathrm{z}$ uczestnictwem w sporcie, wyjazdy $\mathrm{w}$ celach treningowych oraz wyjazdy na wydarzenia sportowe (WEED, BULL 2004, s. 124-131). Rodzi się pytanie, czy takie określenie turystyki sportowej nie wypacza treści powszechnie stosowanej definicji turystyki? Odpowiedź na powyższe pytanie jest dla mnie jednoznaczna, turystyka jest jedna, natomiast motywacje podróży turystycznych są różnorodne. I motyw uczestnictwa w wydarzeniach sportowych (czynnego lub biernego) jest tylko jednym z wielu motywów wyjazdów turystycznych. Nie jest zatem samoistnym „bytem”, a co się z tym wiąże również takim bytem nie jest turystyka sportowa.

Komplikacje semantyczne związane z tzw. turystyką sportową wiążą się także z obserwowaną współcześnie modą na aktywny styl spędzania czasu wolnego w czasie wakacji, weekendów. Czy osoba spędzająca urlop 
w nadmorskiej miejscowości uprawiająca jogging, jeżdżąca dla przyjemności na rowerze, grająca w tenisa ziemnego jest tradycyjnym turystą wypoczynkowym, czy być może już turystą sportowym?

Wydaje się uzasadnione uznanie za turystykę sportową tylko i wyłącznie te wyjazdy, dla których głównym motywem jest bierny udział $\mathrm{w}$ wydarzeniach sportowych (kibice) lub czynny udział $\mathrm{w}$ amatorskich imprezach sportowych (np. maratonach biegowych, spływach, rajdach). Pozostałe typy wyjazdów trudno nazwać turystyką sportową, bowiem uczestniczą w nich sportowcy zawodowcy (efekt komercyjny) albo osoby, dla których głównym celem jest sport jako taki, a nie te elementy, które od dawna przypisane są turystyce. Niełatwo także znaleźć granicę pomiędzy pojęciami dotąd funkcjonującymi w terminologii turystycznej, takimi jak: „turystyka kwalifikowana", "turystyka aktywna" a pojęciem „turystyka sportowa". Podobnie trudno jest wskazać umiejętności (predyspozycje), jakie powinni posiadać uczestnicy turystyki sportowej.

Turyści biorący udział w tzw. turystyce sportowej korzystają najczęściej z ogólnej infrastruktury turystycznej (noclegi, baza gastronomiczna, transport, informacja turystyczna) oraz z urządzeń sportowo-rekreacyjnych dostępnych dla wszystkich turystów, niezależnie od motywacji ich przyjazdów do miejsc wypoczynku. Tylko niewielka część bardzo specjalistycznych urządzeń sportowo-rekreacyjnych adresowana jest do osób mających konkretne umiejętności (np. mariny żeglarskie, ścianki wspinaczkowa, tory kolarskie itp.), ale nawet z tych obiektów i urządzeń mogą korzystać turyści, którzy przyjeżdżają na wakacje, weekendy, czyli są dla mnie tradycyjnymi turystami.

W związku z niemożnością jednoznacznego, precyzyjnego zdefiniowania turystyki sportowej, trudno określić skalę i sezonowość tego zjawiska, a także miary pozwalające wskazać, jaka część ogółu podróży turystycznych może być zaliczana do tzw. turystyki sportowej. W miarę proste wydaje się oszacowanie liczby turystów-kibiców na najważniejszych międzynarodowych imprezach sportowych (na imprezach krajowych już zdecydowanie trudniej), natomiast określenie skali tego typu zjawiska podczas wyjazdów urlopowo-wakacyjnych czy weekendowych jest zadaniem karkołomnym, a zdaniem piszącego te słowa także zbytecznym.

Reasumując swoje rozważania pragnę podkreślić raz jeszcze, że turystyka jest postrzegana jako zjawisko interdyscyplinarne, co wynika z różnorodnych motywacji osób wyjeżdżających poza zwykłe swoje otoczenie, w szeroko rozumianych celach wypoczynkowych, ale nie oznacza to, iż funkcjonują niejako niezależne od siebie "różne turystyki", w tym turystyka sportowa.

Coraz częściej w naukowej terminologii dotyczącej turystyki pojawiają się nowe, „modne” pojęcia niemające uzasadnienia naukowego, a wprowadzające do tejże terminologii istotny chaos semantyczny. Do takich pojęć zaliczam także "turystykę sportową", określenie robiące obecnie karierę w polskiej literaturze turystycznej, określenie, które próbuje przekształcić dotychczasowe pojęcia "turystyka kwalifikowana" i "turystyka aktywna" w jeden syntetyczny agregat pojęciowy, niestety bez pozytywnego rezultatu.

\section{Bibliografia}

SMITH A., 2001, Sporting a new image? Sport-based regeneration strategies as a means of enhancing the image of the city tourist destination, [w:] Sport in The City. The role of sport in economic and social regeneration, Ch. Gratton, I. Henry (eds.), Routledge, London.

STANDEVEN J., DE KNOP P., 1999, Sport Tourism, Human Kinetics, Champaign, Illinois.

WEED M.E., BULL C.J., 2004, Sport tourism: Participant, policy and provider, Elsevier Butterworth-Heinemann, Oxford.

Leszek Butowski

Uniwersytet Warmińsko-Mazurski w Olsztynie

\section{TURYSTYKA SPORTOWA - BYT RZECZYWISTY CZY WIRTUALNY?}

W polskiej literaturze przedmiotu jeszcze w latach $70 . \mathrm{XX}$ w. ukształtował się podział turystyki ze względu na motywy podejmowanych podróży oraz rodzaj wykorzystywanych walorów turystycznych. Zgodnie z tymi kryteriami wyróżniono: turystykę wypoczynkową (wypoczynkowy motyw wyjazdów), turystykę krajoznawczą (motyw poznawczy) oraz turystykę kwalifikowaną (możliwość realizacji hobby, pasji itp.) (ROGALEWSKI 1974). Podział ten, choć obecnie trochę anachroniczny, pozostaje $\mathrm{w}$ jakimś stopniu przydatny zwłaszcza do celów dydaktycznych. Jego głównym mankamentem jest jednak niekompletność. Nie obejmuje on bowiem pewnych nowych form turystyki, których dynamiczny rozwój nastąpił w ostatnich dekadach. Jego niekompletność wynika także z rozszerzenia samej definicji turystyki, która zaczęła obejmować również np. podróże $\mathrm{w}$ interesach (tzw. turystyka biznesowa). Wydaje się jednak, że w celu przeprowadzenia dyskusji nad zakresem znaczeniowym 